\title{
REGULATORY GOVERNANCE IN THE LATIN AMERICAN TELECOMMUNICATIONS SECTOR
}

\author{
Luis H Gutiérrez \\ Department of Economics \\ Universidad del Rosario \\ Calle 14 No 4-69 \\ Bogotá, Colombia \\ lgutierr@claustro.urosario.edu.co \\ Telephone: $(57+1)$ 297-0200, ex. 664 \\ FAX: $(57+1) 344-5763$
}

March 2002*

\begin{abstract}
Starting with Chile in the early 1980s, Latin American countries have pushed telecommunications reform to create regulatory environments that encourage private investment, especially foreign investment. I look at regulatory trends in telecommunications in 24 Latin American and Caribbean countries during 1980-97 and construct an index based on the following aspects: autonomy, accountability, clarity of roles and objectives, transparency and participation, and the type of legal mandate that creates a regulatory body. The index shows clearly that, in general, most countries embraced strong regulatory reforms along the lines recommended by experts and practitioners. The index also correlates well with main political, risk, economic and telecommunications variables.
\end{abstract}

JEL Class: L5, L9

Keywords: Telecommunications, regulation, regulatory governance and privatization

\footnotetext{
* I thank Sanford Berg for encouraging me on the subject and for his constructive comments and editorial suggestions. All errors are mine.
} 


\section{Introduction}

In the last two decades, economists have given more attention to institutional factors as part of the explanation for differences in countries' economic development. Institutional economics has a long tradition, but it has been formally incorporated into theoretical economic models and empirical research only recently. ${ }^{1}$

Although some analyses of how the institutional environment affects economic growth have been done using sources like the Polity III index, the Gastil Liberty index and indexes developed by specialized country-risk agencies, like ICRG (International Country Risk Guide) no study has undertook any effort to construct an index trying to encompass the main aspect a regulatory body should have. ${ }^{2}$ I examine the theoretical aspects that a regulatory framework for telecommunications should encompass and report the first estimates of a regulatory framework index.

As the world economy becomes more integrated, recognition of the need for expanded and modernized telecommunications services has pervaded the plans and policies of most Latin American countries (Hudson 1997). Telecommunications reform has been implemented in almost all the countries in the region, although the degree or depth of reform has been different across countries (Gutierrez 2000).

In this study, I look at trends in the telecommunications regulatory governance in Latin America and the Caribbean. Efforts to build a sound regulatory environment for the telecommunications sector have been fruitful. The regulatory framework index presented in Section 4 shows that almost all countries studied have progressed considerably in this area. The

\footnotetext{
${ }^{1}$ Specifically, see the collection of articles in Alston et al. (1996).

${ }^{2}$ The closest study might be Henisz and Zelner (2001) who used an index of political constraints. Growth models have made extensive use of institutional and political factors. See Barro (1996), Knack and Keefer (1995), and Keefer and Knack (1997) among others. Recently, the World Bank has used the ICRG index to measure institutional developments in Latin America; see Burki and Perry (1998) for details.
} 
next section gives a general overview for a sample of Latin American countries, including the condition of polity in the region before and during regulatory reform.

\section{Context of Latin American Telecommunications Reform}

In the 1980s the debt crisis that hit almost all Latin American countries brought lower or negative economic growth rates, an increase in poverty, a broader gap in the distribution of income, and higher levels of unemployment. To cope with these problems, in the mid-1980s, international organizations like the World Bank, the Inter-American Development Bank (IDB) and the International Monetary Fund (IMF) demanded that governments in the region undertake broad reforms. Some called this set of structural policies the "Washington Consensus" (see Williamson 1990).

Although countries embarked on telecommunications reform at different times, it is clear that overall economic conditions were not ideal. Low annual growth rates suggested a low demand for telecommunications, but the region continued its integration with the world economy (see Table 1). Furthermore, greater levels of urbanization in the region reduced the cost of deploying telecom networks.

Table 1: Economic, Political and Demographic Indicators for Latin America Indicators (number of countries in parentheses) 1996-97

Demand and Cost Indicators

GDP per capita (US\$1995) (24)

$\begin{array}{lcl}2,493 & 2,662 & 2,858 \\ 1.25 & 1.65 & 3.46 \\ .425 & .581 & \text { NA } \\ .614 & .788 & \text { NA } \\ 60.28 & 62.79 & 63.12\end{array}$

Political and Risk Indices

Democracy-GOVTYPE (21)

1.40

1.93

2.10

Gastil-Political Rights (22)

0.69

0.73

0.75 


\begin{tabular}{|c|c|c|c|}
\hline Gastil-Civil Rights (22) & 0.67 & 0.69 & 0.70 \\
\hline Institutional InvestorB/(20) & 21.26 & 25.78 & 32.38 \\
\hline ICRG (22) & 21.69 & 28.24 & 30.98 \\
\hline Economic Freedom Index (19) & 4.79 & 5.55 & 7.00 \\
\hline POLCON (21) & .299 & .328 & .376 \\
\hline \multicolumn{4}{|l|}{ elecommunications Indicators } \\
\hline \multicolumn{3}{|l|}{ Framework Index-RFI (22) } & 0.75 \\
\hline $\begin{array}{l}\text { Cellular subscribers per } 100 \\
\text { inhabitants (24) }\end{array}$ & 0.01 & 0.31 & 1.14 \\
\hline Main lines per 100 inhabitants*/ (24) & 6.2 & 8.9 & 11.4 \\
\hline TELEDENSITY & & & \\
\hline
\end{tabular}

NOTE: The countries in the samples are Argentina, Barbados, Belize, Bolivia, Brazil, Chile, Colombia, Costa Rica, the Dominican Republic, Ecuador, El Salvador, Guatemala, Guyana, Honduras, Jamaica, Mexico, Nicaragua, Panama, Paraguay, Peru, Suriname, Trinidad and Tobago, Uruguay and Venezuela. The variables are described in the Appendix.

Williamson (1998) states that the new institutional economics has two dimensions. The macro level consists of formal and informal rules (customs, constitutions, laws, etc.), while the micro level deals with the institutions of governance referred to as polity. Despite poor economic performance, the region was a winner at the macro level of polity and in the way international analysts perceived the region. The well-known indexes ICRG and Institutional Investor, which reflect external analysts' view of the institutional factors affecting the region, show increases that range from 11 to 29.4 percent when comparing the second half of the 1980s with the first half of the 1990s. The region, then, progressed remarkably in this regard. Recently an index of political constraints that involve checks and balances for government powers (executive, legislative, and judicial) also shows that the region has enhanced its political dimensions. The index called POLCON went from .299 in the late part of 1980s to .376 in the second half of the 1990s.

Other important indicators are related to the political headway Latin America has made in the last fifteen years. The Govtype index shows political stability or level of democratization. As 
shown in Table 1, in the first half of the 1990s, the governments of the region leaned toward more democratic processes reflecting a broader social consensus. The two Gastil indexes for political and civil rights also show a slight increase for more open and democratic societies in the region. The Economic Freedom Index, which judges economies' degree of openness, reflects how the region as a whole became more integrated in world markets.

In the telecommunications sector, the region as a whole achieved good results. Progress is apparent in both mobile and fixed telephony. The indicator of main phone lines per 100 inhabitants (or teledensity) increased from six to almost nine lines. Although this is still far below the level of developed countries, Latin America's rate is now twice that of Asia's (5.1 teledensity when Japan is excluded) and about five times the African average of teledensity (2.0 in 1997).

More recently (1996-97), the performance of the above indicators has kept improving. An important demand factor for main phone lines is GDP per capita, which has increased regionally by almost 3.5 percent (annual rate). In addition, the ICRG and Institutional Investors indicators increased between 9.9 and 24.5 percent compared to the first half of 1990s. The telecommunications indicators increased greatly, especially the total number of cellular phones per 100 inhabitants.

Yet, overall progress in the region has been mixed. Economic and financial developments that followed the Mexican crisis of 1995 and Brazil's of 1998 threaten and blur the future of the region. Many factors keep Latin America's expectations low. According to Stiglitz (1998, 1), a leading world economist, "That [Washington] consensus ... focused on privatization, but paid too little attention to the institutional infrastructure that is required to make markets work, and especially to the importance of competition."

\section{The Building of Regulatory Framework for Telecommunications}

Why regulate the telecommunications sector? Many cite market-failure arguments. From the point of view of the positive political economy, the telecommunications sector is (was) a natural monopoly, so only a few operators can provide telecommunications service profitably at 
lower cost. However, this gives rise to a privileged situation, and dead-weight loss will appear if the market is left unregulated. Thus, regulation is justified.

A second explanation involves imperfect or asymmetric information regarding service quality, technologies that may not be easily compatible, and so on. Regulation is said to improve the social outcome because regulators can supply information about a provider's service quality and force the provider to maintain a given minimum level of quality. Also, the regulator may set some technological standards for compatibility, improving the well-being of the society.

A third justification for regulation involves the public good and external effects. The use of the electromagnetic spectrum is controlled because, if left unregulated, people or operators will use them freely, interfering with each other's transmission and making communications impossible. From a normative approach it is said that government should regulate because telecommunications services are a necessary good. Pricing and subsidy policies help countries achieve the goal of universal service by optimizing the social deployment of networks.

Without going into the details of the politics of regulation, it suffices to say that most of these arguments have been questioned. This has led some developed countries (e.g., New Zealand) to abolish regulatory institutions. In Australia, the functions of telecom regulators have been partially absorbed by competition commissions. Paradoxically, while this kind of questioning is growing in developed countries, the opposite trend is on the rise in developing countries, largely because institutions like the World Bank and IDB keep urging the creation and strengthening of regulatory bodies.

\subsection{Design of Regulatory Institutions}

Economists have been aware of characteristics common to natural monopolies in public utilities since at least 1902 when Farrer (quoted in Newbery 1999, 28), anticipating the basics for regulatory involvement, mentions "economies of scales, capital intensity, nonstorability with fluctuating demand, locational specificity generating location rents, producing necessities or essential for the community and involving direct connections to customers.” Levy and Spiller 
(1994) summarize the conjunction of these characteristics as follows. First, the technologies have important economies of scale and scope. Second, most of a utility’s assets are highly specific and non-redeployable in other activities without great costs. Third, the services provided are considered necessary goods. Altogether, these three characteristics undercut the ability of ordinary market mechanisms to deliver first-best performance.

The first characteristic means there will likely be only a few providers of telecom services. Therefore, governments cannot rely on competitive markets to prevent the abuse of market power. The second characteristic implies that a large proportion of the investment (fixed) can be considered as sunk, giving governments the incentive to behave opportunistically once investment is undertaken. In the extreme case, government can take over the operation of the firm. More likely, government may expropriate value administratively by setting prices below their long-run average incremental costs or by imposing some specific technical conditions concerning the purchase of equipment, labor contracts and so on. Operators in that situation have few options. They will prefer to stay in the market to the extent their operating returns exceed their return from shutting down and deploying their assets elsewhere.

The third characteristic signals the fact that the pricing of utility services is likely to be very political. As Levy and Spiller $(1994,204)$ state, "The combination of significant investment in durable, specific assets with the high level of politicization of utilities has the following result: utilities are highly vulnerable to administrative expropriation of their vast quasi-rents." These points partially explain the perceived need for an administrative agency insulated from undue political pressures.

Levy and Spiller (1994, 1996) look at regulation as a design mechanism with two dimensions: governance and incentives. For them, regulatory governance involves the creation of a transparent and predictable regulatory system that can be sustained over time for utilities in different sectors. Regulatory incentives are the mechanisms that pertain to pricing, subsidies and other operating policies. I consider regulatory governance as the key element in the creation of a 
regulatory framework for telecommunications. Regulatory incentives improve sector performance only if there is strong regulatory governance.

Regulatory governance is determined basically by a country's institutional endowment. In countries with strong regulatory governance, well-known checks and balances limit executive discretionary power. The stronger the regulatory governance, the stronger the constraints on executive and legislative discretion. For the telecommunications sector, the existence of a specific regulatory framework is important for sector development. ${ }^{3}$ Although private investors look at the overall regulatory governance in a country, in developing countries they also look at whether there is a specialized regulatory authority that credibly safeguards the workings of the specific sector of interest.

The attributes to be taken into account when creating a regulatory framework involve theoretical and practical considerations. These are documented below to provide the rationale for a regulatory index developed later.

\subsection{Approaches to the Regulatory Framework in Telecommunications}

Practitioners have long recognized the need for regulatory bodies for utility sectors ${ }^{4}$ and have stipulated some attributes that such regulatory bodies should have. I use their work in constructing a regulatory framework index for telecommunications.

The regulatory framework can be thought of as two parts: structure and process. Structure includes the distribution of regulatory tasks among different levels of the government, the objectives and empowerment given to each agency and the procedures for choosing the regulatory agents. Process includes the mechanisms for communication governing the potentially

${ }^{3}$ The focus of this paper and the index is on basic telecommunications services, but future regulatory framework indexes must include all kinds of telecommunications services, like the valued-added services, mobile telephony and Internet.

4 "Regulatory body" is defined as the individual, board or administrative agency making decisions on regulatory matters. See ITU (1993), Tyler and Bednarczyk (1993), Miller (1994), Schultz (1994), Townsend (1994), Sinha (1995), Tenenbaum (1996), Cave (1997), Melody (1997b), Stern and Holder (1999), Noll (1999), and Kennard (1999). 
overlapping functions among different levels of the government, the ways to overcome conflict and the length and span of control of different regulatory bodies. As Stern $(1997,72)$ points out, the arguments for an independent regulatory agency may be more compelling for "economies with slow growth in demand for utility investment and/or macroeconomic credibility with high indebtedness.”

In the initial design of the regulatory body, structure should matter more than process. According to Stern (1994) and Stern and Holder (1999), the main features of a regulatory body should be: autonomy, accountability, clarity of roles and objectives, transparency and participation. The first three aspects relate to the structure of the regulatory framework, the last two relate to process.

\subsubsection{Autonomy/Independence}

Concerning degree of independence/autonomy, ITU (1993) notes three distinct dimensions that may be temporally linked or not.

1) independence from operational activities (i.e., the regulatory body is separate from the agency or unit that provides the telecommunications services),

2) independence from interested parties, such as industrial customers,

3) degree of independence from the executive branch of the government, which sets broad policy for the sector.

Some Latin American countries - Argentina, Brazil, Chile and Colombia, for instance undertook the first regulatory separation in the 1980s. This first step is the first element in the regulatory framework index. In Latin America, regulatory responsibility was usually given to a unit within the Ministry of Post and Telecommunications. Although regulators were still subject to daily political interference and executive discretion, it was a beginning and significant because regulation by the agency associated with the operating telecom activities cannot be impartial. Another potential benefit from separation of operation and regulation is a separate body of 
bureaucracy more specialized in regulatory matters. Such a bureaucracy might be more willing to back up the privatization process or promote further liberalization, given an understanding of the sector and the fact that status and salary are no longer linked to operations. Although this dimension of independence has been neglected in most analysis, the chairman of the Federal Communications Commission (FCC) has said, “The defining feature of an independent regulatory body is that the regulator is separate from, and not accountable to, any provider of telecommunications services. To ensure that the regulator is, in fact, impartial, the regulatory body and its staff should not have a direct or indirect financial interest in any of the entities being regulated. Inevitable conflicts of interest arise when government controls both the regulatory agency and the dominant players in the market” (Kennard 1999, I-2).

The organizational structure for telecom regulation takes different forms depending on the overall regulatory governance and polity present in a country. In general, the following three forms are of interest for Latin American telecommunications:

1) A regulatory authority within the government ministry responsible for telecommunications, as in Chile, France, Germany and some Asian countries,

2) A fully autonomous regulatory body empowered to make decisions not subject to review by ministers, such as the FCC in the United States,

3) A semi-autonomous regulatory agency whose decisions are generally autonomous but sometimes subject to review by ministers, as is common in Latin America. ${ }^{5}$

Degree of independence is an arguable aspect. ${ }^{6}$ To understand independence, we can use the FCC as a benchmark. Although courts may challenge its decisions, it is a fully autonomous

\footnotetext{
${ }^{5}$ I use semi-independent in a broad sense that may be highly controversial. Tenenbaum (1996, 32) states that "what people really mean by an independent regulator entity is a government entity that does not have to get the approval of the prime minister or other high-level political authorities to raise (or lower) tariffs," but this definition may be too restrictive.

${ }^{6}$ For details regarding factors that may favor or discourage the three types of independence, see ITU (1993) and Stern (1997).
} 
regulatory body empowered to make decisions not subject to review by any secretary or the executive branch. However, such a regulatory body may be impossible for any Latin American country. As Melody (1997a, 198) states, "An FCC-type independent regulatory agency is a unique product of the US constitutional system, with its elaborate division of powers among executive, legislative and judicial branches of governments. Some analysts view the public utility regulatory agencies in the US, including the FCC, as quasi-legislative and quasi-judicial organizations. They have broad mandates and significant freedom both to interpret and to enforce their mandates. Few countries have governmental structures that have permitted such a degree of independence, at least so far. Some even view such degree of independence as an abdication of the political responsibility of elected officials [italics added]."

Some countries have kept their regulatory body within a particular ministry (Chile, Barbados, Belize and Uruguay), while countries like Suriname have not taken even the first step toward separating the regulatory authority from operational activities. Some countries have established a telecommunications regulatory agency (Brazil, Colombia, Dominican Republic, Ecuador, Peru, Paraguay and Venezuela) while others have a non-specialized regulatory body (Bolivia, Costa Rica, Jamaica, Nicaragua and Panama). The legislation backing up the level of regulatory authority varies. Some countries have opted for specific laws, while others have enacted decrees.

Table 2: Type of Telecom Regulatory Agency

\begin{tabular}{|c|c|c|c|}
\hline Country & Name of Agency & $\begin{array}{l}\text { Year of*/ } \\
\text { Creation }\end{array}$ & Created by \\
\hline Argentina & $\begin{array}{l}\text { Comision Nacional de } \\
\text { (Tele)Comunicaciones }\end{array}$ & $\begin{array}{l}1991 \\
1996 \\
1997\end{array}$ & $\begin{array}{l}\text { Executive Decree 1185/90; } \\
\text { Decree 80/97; }\end{array}$ \\
\hline Barbados & Public Utility Board & 1978 & Public Utility Act \\
\hline Belize & Office of Telecommunications & 1991 & NA \\
\hline Bolivia & $\begin{array}{l}\text { Superintendencia de } \\
\text { Telecomunicaciones }\end{array}$ & 1994 & Law 1600 of 1994 \\
\hline Brazil & $\begin{array}{l}\text { Agencia Nacional de } \\
\text { Telecomunicaciones }\end{array}$ & 1997 & $\begin{array}{l}\text { Law 9.472/97 and Decree } \\
2338 / 97\end{array}$ \\
\hline Chile & Subsecretaria de Comunicaciones & 1977- & Decree-Law 1762/77 \\
\hline
\end{tabular}




\begin{tabular}{|c|c|c|c|}
\hline Colombia & $\begin{array}{l}\text { Comision de Regulacion de } \\
\text { Comunicaciones }\end{array}$ & $\begin{array}{l}1992 \\
1994-\end{array}$ & $\begin{array}{l}\text { Decree 2122/92 and Law } \\
142 / 94\end{array}$ \\
\hline Costa Rica & $\begin{array}{c}\text { Autoridad Reguladora de Servicios } \\
\text { Publicos }\end{array}$ & 1996 & Law 7593/96 \\
\hline Ecuador & $\begin{array}{l}\text { Comision Nacional de } \\
\text { Telecomunicaciones } \\
\text { Secretaria Nacional de } \\
\text { Telecomunicaciones } \\
\text { Superintendencia de } \\
\text { Telecomunicaciones }\end{array}$ & $\begin{array}{l}1992 \\
1995\end{array}$ & $\begin{array}{c}\text { Special Law of } \\
\text { Telecommunications } \\
\text { - Reformation Law to the } \\
\text { Law of } \\
\text { Telecommunications }\end{array}$ \\
\hline El Salvador & $\begin{array}{l}\text { Superintendencia General de } \\
\text { Telecomunicaciones }\end{array}$ & 1996 & $\begin{array}{lcc}\text { Decree } & 142 / 97 \quad \text { or } \\
\text { Telecommunications Law }\end{array}$ \\
\hline Guatemala & $\begin{array}{l}\text { Superintendencia de } \\
\text { Telecomunicaciones }\end{array}$ & 1996 & Decree 94/97 \\
\hline Guyana & Public Utility Commission & 1990 & $\begin{array}{l}\text { Public Utility Commission } \\
\text { Act }\end{array}$ \\
\hline Honduras & $\begin{array}{l}\text { Comision Nacional de } \\
\text { Telecomunicaciones }\end{array}$ & 1995 & Decree 185/95 \\
\hline Jamaica & Office of Utilities Regulation & 1995 & $\begin{array}{llr}\text { Office } & \text { of } & \text { Utility } \\
\text { Regulation } & \text { Act. } & \text { Amended } \\
\text { in } 2000 & & \end{array}$ \\
\hline Mexico & $\begin{array}{l}\text { Comision Federal de } \\
\text { Telecomunicaciones }\end{array}$ & 1996 & Presidential Decree \\
\hline Nicaragua & $\begin{array}{l}\text { Instituto Nicaraguense de } \\
\text { Telecomunicaciones y Correos }\end{array}$ & 1995 & Law 200/95 \\
\hline Panama & $\begin{array}{l}\text { Ente Regulador de los Servicios } \\
\text { PSblicos }\end{array}$ & 1997 & Executive Decree 73/97 \\
\hline Paraguay & $\begin{array}{l}\text { Comision Nacional de } \\
\text { Telecomunicaciones }\end{array}$ & 1995 & Law 642/95 \\
\hline Peru & $\begin{array}{l}\text { Organismo Supervisor de la } \\
\text { Inversion Privada en } \\
\text { Telecomunicaciones }\end{array}$ & $\begin{array}{l}1991 \\
1993\end{array}$ & Supreme Decree 013/93 \\
\hline Dominican Republic & $\begin{array}{l}\text { Instituto Dominicano de } \\
\text { Telecomunicaciones }\end{array}$ & 1998 & Law 153/98 \\
\hline Suriname & Telesur & 1980 & Decree C-38 \\
\hline Trinidad \& Tobago & Public Utility Commision & N.A. & N.A \\
\hline Uruguay & $\begin{array}{l}\text { Administration Nacional de } \\
\text { Telecomunicaciones }\end{array}$ & 1974 & Decree-Law 14.235/74 \\
\hline Venezuela & $\begin{array}{l}\text { Comision Nacional de } \\
\text { Telecomunicaciones }\end{array}$ & 1991 & $\begin{array}{l}\text { Presidential } \\
1826 / 91\end{array}$ \\
\hline
\end{tabular}

*/ First year shows the year of creation; additional years date modifications that change or restructure the regulatory body.

Source: ITU (1998a,b), Lewington (1997), Harper (1997), Pyramid Research (1998) and legislation from the countries. 


\subsubsection{Accountability}

According to Stern and Holder (1999, 38), the regulatory framework "should 1) ensure the efficient provision of services to consumers at the minimum necessary prices and 2) support private investment by continuing to allow companies the reasonable expectation of a normal real rate of return." But there are other players besides consumers and operators in the sector. In terms of the organizational design approach, the legislative or the executive power is the political principal. In reality, despite the fact that agencies are supposed to care for consumers' welfare, regulators are not accountable directly to them, but to the legislative or executive power and the operators within the sector.

Because regulators' decisions can affect operators' incentives and outcomes, decisions are usually subject to challenge via some appeal mechanism. The existence of a mechanism to resolve disputes between the regulatory body and operators or conflicts between operators is called due process. Accountability is to the executive power in most Latin American countries. The right of appeal should be limited to questions of regulatory process rather than concerned with substantive policy issues. Finally, regulatory behavior (distinct from decisions) needs to be accountable. Regulators can have incentives for wrongdoing, and there should be clear mechanisms that limit or curb potential misbehavior.

Most countries in the sample have different levels of accountability, mostly entrusted in mechanisms of appeal directly to the courts. For instance, Chile is recognized for its strong and independent judiciary although it does not have an independent regulatory body. In Colombia, the

courts upheld local phone operators that appealed their right to enter long-distance service markets, and the regulatory body was forced to open that market (in a restricted way). 


\subsubsection{Clarity of Roles and Objectives}

In Latin America, a politically appointed minister of post and telecommunications usually sets telecommunications policy. Recognizing that presidentialism ${ }^{7}$ dominates the politics of most countries in the sample is important for analysis because the president can bargain with rival political parties when making appointments to align the opposition with the presidential agenda. In most Latin American countries, some regulatory roles are shared between the regulatory body and other government agencies, particularly the ministry of telecommunications. ${ }^{8}$ This may be viewed as a bad design of regulatory governance because of the potential overlapping of tasks and the increased cost of separate agencies. However, this may have been the best decision, given the relative market power and influence of the (new) telecom players. The separation of responsibilities (roles) between different regulatory bodies acts as a mechanism to prevent (or reduce) regulatory capture by the interest groups and to improve commitment (see Tirole 1994). Furthermore, theoretical research suggests that when commitment by the government to the regulatory contract is limited or when renegotiation is a likely outcome of the reform process, separation of powers between different regulatory agencies is a better design (Spiller 1996).

From the point of view of practitioners, concerns about clarity of roles involve the following questions. Does the legislation establish unambiguously which entity is responsible for what regulatory functions? Are there functions carried out jointly between the regulator and the relevant minister(s), or any that are ambiguous? Is it clear where the regulator has an advisory role rather than a decision-making role?

Clarity of roles is important in the supervision of the dominant telecom operator. This has been an important reason for creation of regulatory bodies. All Latin American countries have had state telecom operators that were monopolies. After privatization and with the exclusivity

\footnotetext{
${ }^{7}$ See Mainwaring and Shugart (1997). "Presidentialism” refers to a political system dominated by the presidency regardless of the majority party in the congress.
} 
periods granted, the public monopolies became private monopolies. A regulatory body is needed to curb the monopolistic incentive to exercise market power, impose high prices and reduce consumers' welfare. ${ }^{9}$ Concession contracts signed with new owners usually include many targets in terms of coverage, quality, price schemes and so on. Without a doubt, oversight of targeted goals is an important function of the regulatory body. In this respect, the regulatory body should have the power to set tariffs for those markets where competition does not exist.

A further mission is assuring technical preconditions for effective operations. If competition is to be allowed, this becomes crucial. There must be clarity regarding numbering plans, number portability, technical standards or rules concerning interconnection. A related concern is effective management of common resources. This includes the allocation of the electromagnetic spectrum, public rights of way and the design of clear mechanisms for allocating those rights. At issue is who is responsible for policing the telecommunications sector, which turns out to be a very important matter. Regulation will be credible if it bites. Thus, a regulatory body may have to issue legally binding orders when it makes a decision (resolution) or when it concludes that an operator is violating a regulatory norm. The recourses available to the regulatory authority if legally binding decisions are persistently violated are also encompassed.

\subsubsection{Transparency and Participation}

Practitioners argue that "regulators in developing countries are always under suspicion because often their first big task is to lift prices up to costs" (Tenenbaum, 1996, 34; see also Stern and Holder 1999, Tyler and Bednarczyk 1993, ITU 1993). The potential for collusion between regulators and the regulated firms means that mechanisms for transparency need to be firmly

\footnotetext{
${ }^{8}$ This multi-agency approach is also present in the United States where "several agencies of the federal government, in addition to regulatory agencies of the fifty states, have important roles to play in the determination of regulatory policy" (Kennard, 1999, II-1).

9 As Pisciotta (1997, 339-40) states, "Most countries engaged in liberalisation commonly experience a need for increased regulation. Licensing, enforcement of license obligations, rate rebalancing and review, interconnection rules, accounting standards and frequency allocation all normally require a significant degree of regulatory oversight - at least until fair competitive market rules are firmly established."
} 
embedded in regulatory design. Three main aspects should be considered: (1) a clear specification of the rules of the game, (2) opening up of the process to take or implement decisions and (3) a mechanism to explain or publicize decisions. Notice that the better the transparency of the regulatory process, the more accountability is imposed on the regulatory authority and the less may be the likelihood of regulatory capture. According to Noll $(1999,44)$, "The agency can be required to conduct all business in public, to refrain from secret contacts with either interested parties or political officials and to release all relevant information pertaining to a decision as well as a preliminary indication of the decision it is likely to make before the actual decision is made.” (See also Smith and Wellenius 1998, 6.)

\subsection{Legal Scope of the Regulatory Framework}

An important feature of regulatory governance in Latin America made explicit by Levy and Spiller (1994, 1996) is the scope of the legislation creating the regulatory bodies and the strength of the judiciary. Analysts emphasize this because many developing countries lack credibility in this regard.

Citing Bolivia, Borner et al. $(1995,19)$ point out that Supreme Decree No. 2247, issued in 1990, contains a series of measures aimed at encouraging private investment by domestic and foreign entrepreneurs. It guarantees equal rights for foreign and domestic investors (Article 31), the same fiscal duties (Article 32) and respect of property (Article 33), no restriction on capital transfers (Article 34) and continued convertibility of the boliviano (Article 35). From the point of view of efficiency, the decree introduced the right policies. The question is whether these policies are credible.

A presidential decree like Supreme Decree No. 2247 seems almost a paradox since a new decree can rescind all former promises. The fact that an executive can implement rights simply by issuing decrees shows that there are no mechanisms for guaranteeing property rights other than the will of the executive. Hardly anything is worse for investor confidence than discretionary power with no institutional safeguards to prevent arbitrary changes in policy. Credibility is not 
established by decree. This point is applicable to all Latin American and Caribbean countries and the political systems governing the region. Following Levy and Spiller, I agree that a regulatory framework introduced through presidential decrees is prone to great instability and hence will not be credible.

Regulatory frameworks created by laws enacted by the elected legislative body are stronger safeguards of stability than those formed by executive decrees. Presidential decrees or simple decrees fail to convey credible signals to private investors. As Table 2 shows, most countries in the region adopted specific laws to create the regulatory body in telecommunications. Others (Argentina, Mexico and Peru) simply published presidential decrees.

Long-term contracts have been common in the water, sewerage, energy and telecommunications industries. Spiller and Sampson (1996) argue that long-term contracts are sometimes the only way governments can credibly commit to not behave opportunistically and that regulation by contract may be the only way to mitigate lack of government commitment. In their study of Jamaican telecommunications history, they show that the highly discretionary power exerted by the executive branch (the prime minister and the relevant minister) spurred government opportunism that, in turn, brought a steady underinvestment in the telecommunications sector by the foreign operator. They also studied the Jamaican judiciary system, which has always been independent and strong. Given a history of opportunism and the strength of the judiciary system in Jamaica, the best design of the regulatory framework was regulation by contract. ${ }^{10}$

A main feature of the Levy and Spiller analysis is the idea that the design of the regulatory framework should be compatible with a country's institutional structure and its legal and administrative traditions. This suggests that regulatory governance can include two different

\footnotetext{
${ }^{10}$ Concession and license contracts have been common in Latin American ownership reforms. Countries like Argentina, Venezuela, Jamaica, Trinidad and Tobago and Mexico signed such contracts, which stipulate the obligations and rights of the operators and the pricing mechanism.
} 
uses of long-term contracts: as a substitute for or complement to a separate regulatory institution (Stern and Holder 1999). The first may be valid in the context of a single monopoly provider, as was the case for telecommunications in Jamaica in 1987. However, that contract is currently subject to hard renegotiations because it limited the ability of government to expand competition in the sector and to reduce the too-high profit level of the $\mathrm{C} \& \mathrm{~W}$ of Jamaica. Because technological advances in telecommunications seem to be unlimited and concession contracts are inflexible, I advocate using concession contracts as a complement to the separate regulatory framework.

As Latin American countries have enacted new constitutions or amended old ones, a key element has been an effort to strengthen and ensure greater independence of the judiciary system. ${ }^{11}$ We should expect a stronger judiciary to be a mechanism for constraining executive or legislative discretion; however, one should not underestimate the difficulties of implementing laws and norms in Latin American countries.

\section{The Regulatory Framework Index}

As Latin America and the Caribbean have become more integrated into international markets over the past decade, there has been a movement toward the creation and strengthening of institutions. Structural reforms have also affected institutions. As state participation decreases, the need for sound and fair institutions increases if private sectors are to expand investments. And with growing urbanization, governments are pressured to create an institutional environment that allows more citizen participation in economic policy development. ${ }^{12}$

Gutiérrez and Berg (2000) based a first attempt to create a regulatory framework index (RFI) for Latin American telecommunications on research by Galal and Nuriyal (1995). Looking at telecom regulation in seven developing economies, Galal and Nauriyal stressed the importance of factors like the level of autonomy and neutrality of the regulatory agency, agency enforcement

\footnotetext{
${ }^{11}$ For more details, see Gargarella (1997).

${ }^{12}$ For more about this topic, see Burki and Perri (1998).
} 
power and the existence of mechanisms for conflict resolution. Gutiérrez and Berg constructed a dichotomous index, giving a score of 1 to a regulatory agency with at least two of the three attributes, and zero otherwise. Although useful, the index had serious shortcomings since it was based on secondary sources and involved a high degree of subjectivity. Also, the dichotomous index reached the upper bound of 1 in one step, at which point some might erroneously believe that countries had achieved complete regulatory development in the telecommunications sector.

The later availability of work by ITU (1993) and Tenenbaum (1996) and more recent work by Stern and Holder (1999) and Kennard (1999) led us to rethink the construction of the index, particularly the problem of how to measure aspects like autonomy and accountability with less subjectivity. To Tenenbaum's four indicators for autonomy, we added two more features: the regulatory body's complete freedom in recruiting its own specialized staff (Estache and Martimort 1999), which involves exemption from civil service salary and recruitment rules to attract highly trained personnel, and appointment of personnel for several years (Noll 1999). ${ }^{13}$

With regard to accountability, ITU (1993) stresses the importance of a right of appeal on questions of regulatory process, although not on substantive policy issues. In addition to due process, another factor is whether more than one body is responsible for regulatory policies. Clarity of roles might include several factors, such as the right of the regulator to set a tariff for basic services or impose fines and punishments. Transparency and participation are reflected in public hearings held prior to decision-making and obligations to publish decisions in the media. All these elements need to be clearly stated in the legal mandate.

Since I posit a developing regulatory framework for telecommunications in Latin America from the beginning of the 1980s, I introduce as a first element the separation of operational and regulatory activities as two different entities. This separation matters regardless

\footnotetext{
13 According to Petrazzini (1997, 365), "The process of building regulatory capabilities in developing countries is proving to be one of the most difficult and elusive tasks of the reform. Acquiring the necessary funds, hiring a diversified and highly professional staff, buffering...can be a slow and painstaking process."
} 
of whether the regulatory tasks were delegated to a government unit or an agency within the related ministry. I call this the ITU/Kennard criterion.

I also incorporate the legal framework that created the regulatory body. As Levy and Spiller note, a number of alternatives may be related to legal norms; for instance, laws voted by the whole congress, presidential decrees and decrees issued by the related minister. I simplify the problem to a matter of laws and decrees only.

Once the main criteria were identified and linked to concepts from the literature, I operationalized them into the index. I reviewed journal articles, books, press releases, Internet websites and, more importantly, the national legislation. ${ }^{14}$ Unfortunately, it was not possible to collect reliable information for all the criteria from all twenty-four Latin American countries in the sample. I gave the most weight to the information extracted from legislation (laws, decrees, resolutions, etc.). Table 3 illustrates how the index was constructed. The dimensions suggested by Stern and Holder are operationalized with the ITU/Tenenbaum criteria. The ITU/Kennard criterion (separation of regulatory and operating activities) follows, along with Levy and Spiller's legal rank and an overall RFI estimate for one year.

Table 3: Regulatory Framework Index (RFI)

\begin{tabular}{|l|l|c|c|c|c|c|l|l|}
\hline & \multicolumn{2}{|c|}{$\begin{array}{c}\text { Autonomy } \\
(1)\end{array}$} & \multicolumn{2}{c|}{$\begin{array}{c}\text { Clarity of Roles } \\
(2)\end{array}$} & $\begin{array}{c}\text { Accountability } \\
(3)\end{array}$ & ITU/K@/ & $\begin{array}{l}\text { Legal } \\
\text { rank/ } \tau\end{array}$ & RFI \\
\hline Country & $\begin{array}{l}\text { Funding* } \\
\text { / }\end{array}$ & Removal*/ & Prices*/ & Fines*/ & Appeal*/ & & & $\cdot$ \\
\hline $\mathrm{X}$ & 1 & 1 & 1 & 0 & 1 & 1 & 1 & \\
\hline
\end{tabular}

NOTE: */ refers to ITU/Tenenbaum criteria; (c/ refers to ITU and Kennard criteria; $\tau$ / refers to the Levy and Spiller criterion.

The further operationalization was to have a dichotomous procedure for every dimension. So, for instance, if the country had a regulatory body with an independent source of financing, I gave it a value of 1 (and zero otherwise). I then averaged the ITU/Tenenbaum criteria. In this way, the average of all five attributes can reach a maximum of 1 and a minimum of zero. For the 
ITU/Kennard criterion, I assigned a 1 if there was separation between the regulatory and operating activities, and zero otherwise. And for Levy and Spiller's legal ranking, I gave a value of 1 for a law and 0.5 for any other kind of legislation backing up the regulatory body.

The last operationalization was to give some weights to each of the three main overall dimensions. There was some subjectivity in this, as I assigned the same weight to every dimension (attribute) because information was available for only a few of the ITU/Tenenbaum criteria. Each factor included for these dimensions has a weight of about 14.3 percent. In the future, when more factors (and dimensions) are added, the weights should be varied accordingly. The ITU/Kennard separation criteria and the Spiller's legal rank also have the same weight.

The index has limitations. First, it tries to measure regulatory governance but not regulatory incentives structure. In the United States, researchers ${ }^{15}$ take the regulatory framework as a given and focus on the relationship between incentive regulation and telco performance, shedding light on the ranking of price regulation, price caps, earnings share and rate-of-return regulation. After all, the FCC and the state regulatory commissions have more than 60 years of experience. My index is an attempt to characterize the regulatory framework and its development in telecommunications for selected Latin American countries.

Second, my index tries to capture the objective aspects that a sound regulatory framework should have. Thus it reflects the letter of law but is silent about the law as applied. When I assign a 1 to countries with legislation that says regulators cannot be freely removed, I am assuming that this is accurate. However, day-to-day politics can deviate from legal theory, as the following example from Bolivia illustrates.

Bolivia's regulatory body has its own budget, and its members are selected by two-thirds of the congress. It has authority to enforce relevant legislation and set tariffs. Its legal status was

\footnotetext{
${ }^{14}$ An informal survey of regulators and industry managers was also considered.

15 See the survey by Kridel et al. (1996) and Berg and Foreman (1996). A more detailed and thorough analysis of incentive regulation in U.S. telecommunications is given in Sappington and Weissman (1996).
} 
conferred by congressional law. It appears an ideal model, but the following report from Pyramid Research $(1998,145)$ reveals shortcomings. "Following controversy over the activities of the first administration at the helm of the Superintendent regarding the awarding of concessions that violated ENTEL's monopoly, the Bolivian Congress voted in a new telecom regulatory administration in October 1997 for a six-year term that will end in 2003. The fact that the Bolivian Congress was able to remove the Superintendent because of a decision that threatened ENTEL's market share does not reflect positively on the autonomy and transparency of the regulatory body. This signifies that the Congress's decision had more weight than the law."

In formulating the index, I did not attempt to correct for such instances by including the beliefs of practitioners or experts about the performance of a regulatory body (as in, say, the various rating systems for U.S. state regulatory agencies). The actual index would reflect only the letter of the legislation and the day-to-day (year-to-year) evolution of regulatory tasks in the regulatory authority. Nor did I include additional factors regarding autonomy, accountability and clarity of roles, not to mention transparency and participation. With more factors, the index would be a more comprehensive measure of changes in a country's regulatory framework standing, but the index value for most of the countries would go down. However, this work realistically can be done.

The index may involve mistakes of interpretation. This is a second-generation effort to construct a useful index, and the research remains only a beginning step toward a more integrated and comparable approach to institutional reform in telecommunications. Availability of better information will allow development of a better index in the future. Other research so far "provides interesting information about the overall effect of reform on several measures of performance.... But to date, this work has not adopted a very comprehensive approach to characterize the institutional and policy differences among reforming countries.... The main research agenda, then, is to combine the richness of institutional detail that one finds in the best 
case studies with a large enough statistical sample to support stronger conclusions about the direct links between distinct policy decisions and ultimate performance. This task is not a small one” (Noll 1999, 59).

\section{The Regulatory Framework Index and Relations to Institutional and Risk Indexes.}

The RFI measures regulatory governance in telecommunications for a sample of Latin American countries. ${ }^{16}$ Exhibits 1-5 compare how the RFI correlates with other measures of overall polity in Latin America, the GDP per capita and some measures of telecommunications performance. I grouped the countries into quintiles for easy comparison (from lowest RFI scores in bottom quintile to highest in the top).

Exhibits 1, 2 and 3 show that the regulatory framework index is, in general, positively related to higher levels of macro polity for the period 1990-97. This suggests that the microinstitutional setting of a utility sector should develop in the same directions as the macroinstitutional environment (captured by Gastil and ICRG indexes). In particular it is worth mentioning the good association of the RFI with the POLCON index showing that governance in telecommunications has moved in the same directions as the overall political constraints. However, as the exhibits show, some small divergence (positive or negative) between the two institutional levels can occur.

Exhibit 4 presents the relation between the 1990-97 average of RFI and GDP per capita. All in all, greater values on the RFI are associated with greater levels of GDP per capita (US\$ 1995), although some countries in a higher quintile are associated with lower levels of GDP per capita. For example, some Central American countries stepped up their attempt to strengthen their telecommunications regulatory bodies with statutes, while more wealthy Caribbean countries have shown little concern for their micro-institutional environment in telecommunications.

\footnotetext{
${ }^{16}$ Gutierrez (2002) contains a more formal test of how the index helps explain performance variables in the telecommunications sector.
} 

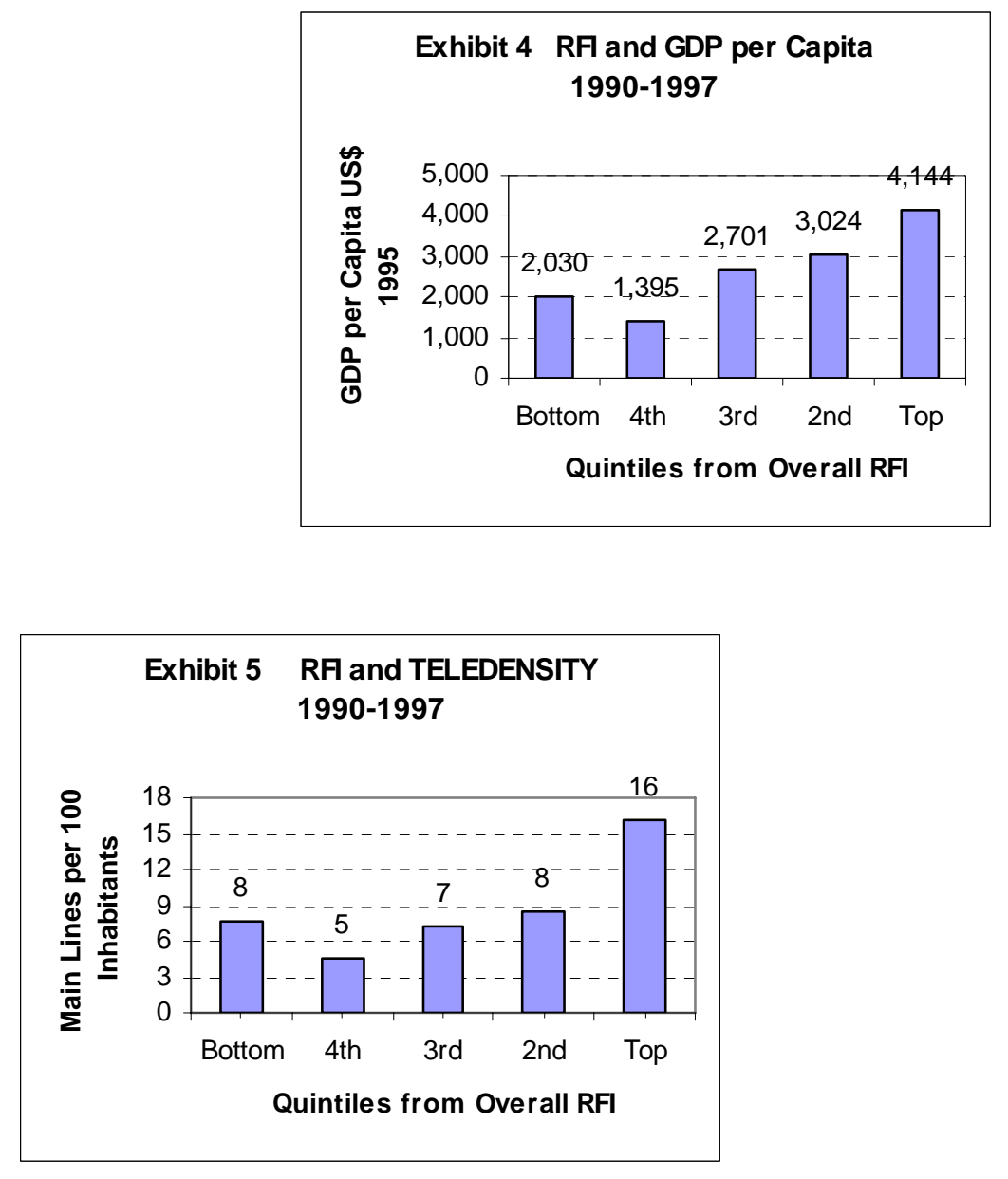

The last exhibit shows the association between the RFI and the level of teledensity (main telephone lines per 100 inhabitants) for the period 1990-97. Increasing teledensity is generally associated with a stronger regulatory framework in telecommunications, but bear in mind that the bottom quintile includes Uruguay (17.8 main lines per 100 people). Uruguay has one of the best average rates of teledensity and generally good political and economic performance during the period, yet it has not reformed its regulatory framework in telecommunications. Uruguay's telecommunications' incumbent is state-owned, there is no new legislation to integrate technological development in the sector, and there was no competition at all during the period analyzed. 
Table 4 presents averages of the RFI for different periods of time. Countries like Chile, the Dominican Republic, and Trinidad and Tobago started well ahead of other countries, but progress in strengthening their regulatory frameworks has been marginal. Chile was one of the first to enact a modern telecommunications law and one of the first to privatize. Yet, with a stable regulatory environment, competition in its telecommunications sector and a sound judiciary, Chile still does not have a regulatory body with independent funding or fixed terms for commissioners. ${ }^{17}$ The index has remained constant for Chile except during 1981-82.

\begin{tabular}{|l|c|c|}
\hline \multicolumn{3}{|c|}{ Table 4: The Regulatory Framework Index for Telecommunications } \\
\hline Country & $1980-89$ & $1991-97$ \\
\hline Argentina & 0.34 & 0.72 \\
\hline Barbados & 0.48 & 0.48 \\
\hline Belize & 0.36 & 0.69 \\
\hline Bolivia & 0.34 & 0.50 \\
\hline Brazil & 0.34 & 0.53 \\
\hline Chile & 0.70 & 0.72 \\
\hline Colombia & 0.34 & 0.67 \\
\hline Costa Rica & 0.14 & 0.40 \\
\hline Dominican Republic & 0.62 & 0.63 \\
\hline Ecuador & 0.14 & 0.63 \\
\hline El Salvador & 0.14 & 0.25 \\
\hline Guatemala & 0.34 & 0.44 \\
\hline Guyana & 0.28 & 0.80 \\
\hline Honduras & 0.14 & 0.36 \\
\hline Jamaica & 0.48 & 0.66 \\
\hline Mexico & 0.34 & 0.49 \\
\hline Nicaragua & 0.14 & 0.34 \\
\hline Panama & 0.14 & 0.24 \\
\hline Paraguay & 0.14 & 0.36 \\
\hline Peru & 0.34 & 0.67 \\
\hline Suriname & 0.14 & 0.14 \\
\hline Trinidad and Tobago & 0.64 & 0.85 \\
\hline Uruguay & 0.24 & 0.37 \\
\hline Venezuela & 0.34 & 0.61 \\
\hline
\end{tabular}

Source: Author's construction.

${ }^{17}$ According to Bitran and Serra (1998, 948), Chile’s judicial authority does not always have the capacity to solve conflicts involving intricate technical or economic issues and "a case study shows that the antitrust agencies are reluctant to apply sanctions or adopt measures when the situations under study involve complex technical problems.” A similar viewpoint can be found in the Pyramid Research (1998) study. 
The Dominican Republic is also interesting, given its long history with a service provider that is a private monopoly. Its telecommunications reform has been oriented more toward opening the market to competition and recently toward developing a more independent regulatory authority. This is an example of a country that lacked an autonomous regulatory body but had a government agency responsible for regulating telecommunications and relatively empowered to set tariffs and fine operators in the sector. It therefore meets some of the ITU/Tenenbaum criteria.

Some countries display a similar evolution in regulatory framework. The Central American countries (El Salvador, Guatemala, Honduras, Nicaragua and Panama) are the latest to adopt specific regulatory measures for public utilities. Some lacked even the ITU/Kennard criterion of separation between operating and regulatory activities just three years ago but are now trying to catch up to other countries in the region. Bolivia, Brazil, Colombia and Per $\delta$ have reached the upper bound of the regulatory framework (Table 3), which means progress in the right direction in terms of the institutional factors included in the index.

Table 5 shows a cross-country comparison of the RFI for different periods of time. As noted, some countries started well ahead in their reform of the regulatory settings, but those that have not furthered reform now lag behind the regional average. By the first half of the 1990s, the Andean countries began catching up, and for the last two years of the study, the larger countries in the region, Brazil and Mexico, entered the group of countries with stronger regulatory framework in the telecommunications sector.

\section{Table 5: Cross-Country Comparisons}

\begin{tabular}{|l|c|c|c|c|}
\hline & $1985-90$ & $1991-95$ & $1996-97$ & $1980-97$ \\
\hline Countries & Chile & Guyana & Colombia & Trinidad \&Tobago \\
& Trinidad \&Tobago & Trinidad \&Tobago & Honduras & Chile \\
& Dominican Rep. & Argentina & Peru & Dominican Rep. \\
& Jamaica & Belize & Bolivia & Guyana \\
& Barbados & Chile & Ecuador & Jamaica \\
& Belize & Ecuador & Guyana & Belize \\
& Guyana & Venezuela & Trinidad \&Tobago & Argentina \\
\hline
\end{tabular}




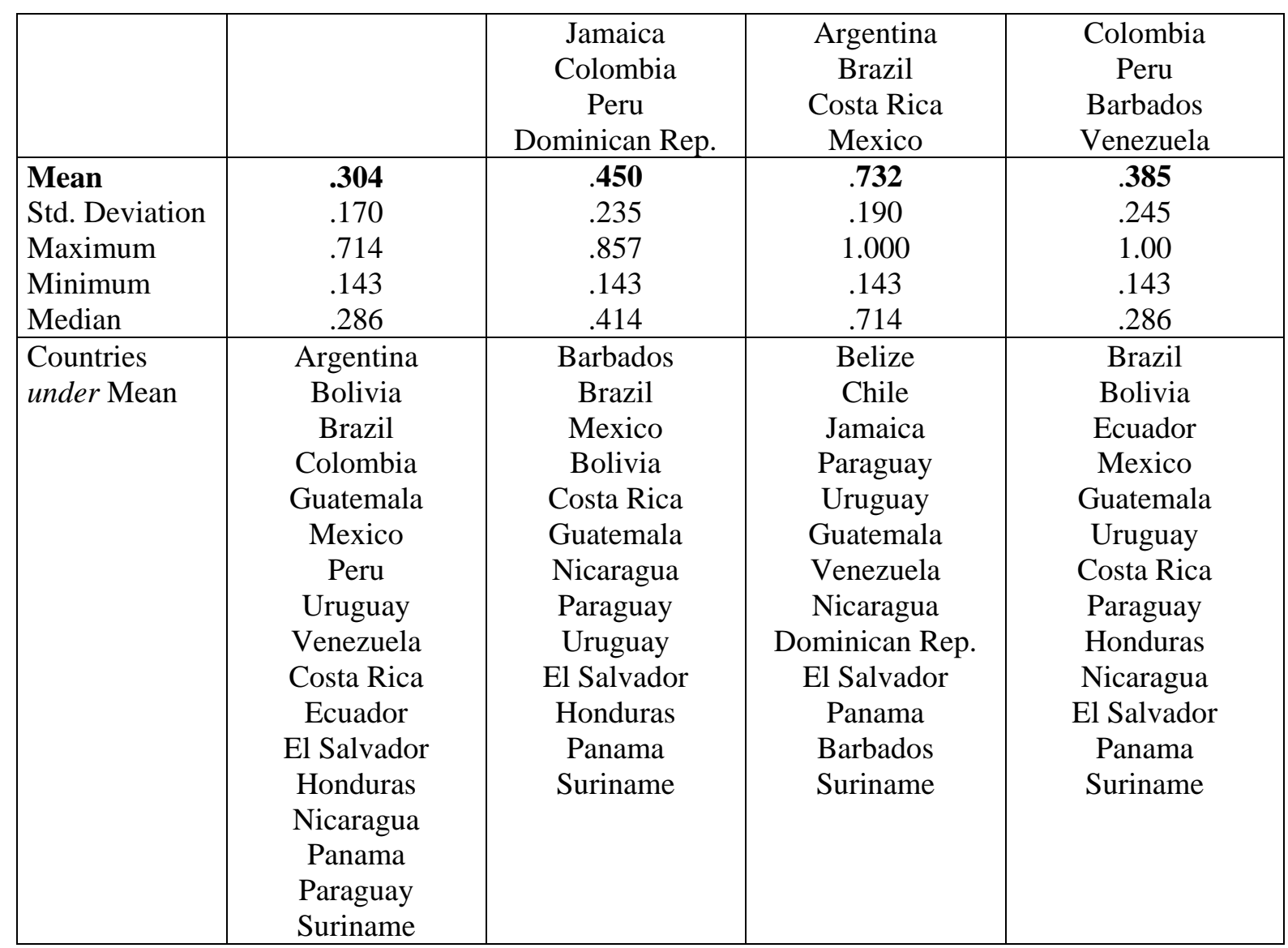

\section{Conclusion}

Telecommunications reform across Latin America and the Caribbean has pushed privatization more than in other regions of the world. After British Telecom in the United Kingdom privatized, the first telecom operator in the western capitalist economies to do so, Latin American countries followed suit. Chile's initiatives served as an important model, but the way privatization took place was different across countries and deserves further study and analysis.

The liberalization of the main telecom markets has been slow despite reform. Unfortunately, at the time of privatization, governments across the region gave monopoly power to the new owners, reducing the benefit of ownership reform. The exclusivity periods granted are about to end in some countries, and open or partial competition will become possible. A byproduct of the concession of exclusivity periods has been the entrenchment of incumbents and the appearance of anti-competitive behaviors. 
The present index of the regulatory framework for the telecommunications sector (basic services) uses the broad categories of autonomy, accountability, clarity of roles, and transparency and participation, the main features recommended by policy analysts and practitioners. To operationalize an index, factors related to these categories were analyzed, such as independent funding for the regulatory body, constraints on executive power to freely remove regulators, the ability of the regulatory body to set tariffs and enforce norms. Consideration was also given to the legal status of the norms that created the regulatory body. Most counties made an effort to put the regulatory framework on a legal foundation, but a major shortcoming of the index is that it reflects only the letter of the legislation. Because events and politics can circumvent the law, the regulatory framework index needs to be extended to incorporate such factors. Nevertheless, related research demonstrates both the feasibility and usefulness of the index. 
APPENDIX: DESCRIPTION OF VARIABLES (sources given in parentheses at end)

MLINES is main telephone lines. Each line represents a connection between a subscriber's terminal equipment and the public switched network, which has a dedicated port in the telephone exchange equipment. Main lines per 100 inhabitants or teledensity is derived by taking (Main Lines/Population) * 100. (See ITU 1997.)

GDPPC is the GDP per capita in 1990 U.S. dollars; TRADEGDP is the ratio (export plus imports)/GDP (World Bank "Economic and Social Indicators 2000 CD-ROM").

URBAN represents the degree of urbanization. It is derived by taking (urban population/total population). (World Bank, "Economic and Social Indicators 2000 CD-ROM").

The ICRG index is compiled by IRIS (Center for Institutional Reform and the Informal Sector, University of Maryland) using information from a private international investment risk-service company that employs experts to provide political and economic risk ratings of countries. I used the composite index made up of five components.

The GOVTYPE index was constructed with data provided by Jaggers and Gurr (1996). I follow Londregan and Poole (1996) and combine the two measures of DEMOC and AUTOC (democracy and autocracy) to construct GOVTYPE. $\mathrm{S}$ = DEMOC - AUTOC.

The Economic Freedom Index was constructed with data provided by the Economic Freedom Network. The index is based on four major areas: (1) money and inflation, (2) structure of the economy, (3) takings and discriminatory taxes, and (4) international trade. I use the simple overall summary ratings. See Gwartney, Lawson and Samida (2000). The data reported in Table 1 is the average between two years (i.e., 19851990, 1990-1995 and 1995-1997). The index is available for every five years starting in 1970 (1985, 1990, 1995 and 1997) at http://www.fraserinstitute.ca/publications/books/econ_free_2000/section_07.html.

INSTINV or Institutional Investor Index is the average of the country credit-rating index that Institutional Investor magazine publishes twice a year (March and September). The index goes on a scale of 0 to 100, with 100 representing countries with the least chance of default. From 75 to 100 banks, each of which provides its own ratings, contribute to the index.

EUROMONEY is the average of the country risk-rating index that EUROMONEY magazine publishes twice a year. The index also goes on a scale of 0 to 100. The index is composed of nine categories, each with a different weighting. Economic performance and political risk account for $50 \%$ of the total index.

CELLSUB variable is the number of cellular subscribers per 100 inhabitants (ITU 1997).

The Structural Policy Index covers 20 countries in the region from 1985 to 1995 . The most important feature of the index is that it reflects policy variables like tariffs, tax rates and so on, and not results variables like ratio of exports to GDP and so on (IDB 1997).

The General Reform Index covers 17 countries in the region from 1970 to 1995 and is a joint work of researchers in the ECLAC.

POLCON is a index constructed by W. Henisz. As he mentions (Henisz and Zelner 2001, 132) the index "was constructed to address the specific issue of concern to investors: the credibility of the policy regime." The index is available at http://wwwmanagement.wharton.upenn.edu/henisz/POLCON/ContactInfo.html. 


\section{REFERENCES}

Alston, Lee J., Thráinn Eggertsson, and Douglass North (1996) Empirical Studies in Institutional Change, Cambridge University Press.

Barro, Robert (1996). “Democracy and Growth,” Journal of Economic Growth 1: 1-27.

Berg, Sanford, and R. Dean Foreman (1996). "Incentive Regulation and Telco Performance: A Primer,” Telecommunications Policy 20: 641-52.

Bitran, Eduardo, and Pablo Serra (1998). "Regulation of Privatized Utilities: The Chilean Experience,” World Development. 26: 945-62.

Borner, Silvio, Aymo Brunetti and Beatrice Weder (1995). Political Credibility and Economic Development. St. Martin's Press: New York.

Burki, Shahid Javed, and Guillermo E. Perry (1998). Beyond the Washington Consensus: Institutions Matter. World Bank: Washington, D.C.

Cave, Martin (1997). "New Developments in Telecommunications Regulation." In The New Research Frontiers of Communications Policy, edited by D. Lamberton. Elsevier: Amsterdam.

Estache, Antonio, and David Martimort (1999). "Politics, Transaction Costs, and the Design of Regulatory Institutions," Policy Research Working Paper 2073. World Bank: Washington, D.C.

Galal, Ahmed, and Bharat Nauriyal (1995). "Regulation of Telecom in Developing Countries: Outcomes, Incentives and Commitment,” Revista de Análisis Económico 10: 41-62.

Gargarella, Roberto (1997). "Recientes Reformas Constitucionales en América Latina: Una Primera Aproximación," Desarrollo Económico 36: 971-91.

Gutiérrez, R. Luis H. (2000). "Privatization and Regulatory Reform in Latin American Telecommunications." In Privatization, Deregulation and Economic Efficiency, edited by M. Kagami and M. Tsuji. Edward Elgar: Cheltenham, UK.

(2002). " The Effect of Endogenous Regulation on Telecommunications Expansion and Efficiency in Latin America." Working Paper Universidad del Rosario.

and Sanford Berg (2000). "Telecommunications Liberalization and Regulatory Governance: Lessons from Latin America." Telecommunications Policy. 24: 865-84.

Gwartney, James, Robert Lawson and Dexter Samida (2000). Economic Freedom of the World: 2000 Report. Fraser Institute: Vancouver.

Harper, Steven (1997). Inside Latin American Telecommunications: A Study of Privatization and Competition in Argentina, Brazil, Chile and Mexico. Telecom Publishing Group: Boston, Massachussets.

Henisz, Witold, and Bennet Zelner (2001). "The Institutional Environment for Telecommunications Investment." Journal of Economics and Management Strategy, 10: 123-47. 
Hudson, Heather E. (1997). Global Connection: International Telecommunications Infrastructure and Policy. Van Nostrand Reinhold: New York.

IDB (1997). Latin America After a Decade of Reforms, Economic and Social Progress in Latin America, 1997 Report. Inter-American Development Bank: Washington, D.C.

ITU (1993). The Changing Role of Government in an Era of Deregulation. ITU Regulatory Colloquium No. 1. International Telecommunications Union: Geneva.

(1997). ITU Database World Telecommunications Indicators 1997. International Telecommunications Union: Geneva.

(1998a). General Trend in Telecommunication Reform 1998, vol. 1. International Telecommunications Union: Geneva.

(1998b). General Trends in Telecommunication Reform 1998: Americas vol. 3. International Telecommunications Union: Geneva.

Jaggers, Keith, and Ted Robert Gurr (1996). “Tracking Democracy's Third Wave with the Polity III Data,” Journal of Peace Research 32: 469-82.

Keefer, Philip, and Stephen Knack (1997). "Why Don't Countries Catch Up? A Cross-National Test of an Institutional Explanation,” Economic Inquiry 35: 590-602.

Kennard, William E. (1999). Connecting the Globe: A Regulator's Guide to Building a Global Information Community. Federal Communications Commission: Washington, D.C.

Knack, Stephen, and Phillip Keefer (1995). "Institutions and Economic Performance: Crosscountry Tests Using Alternative Institutional Measures,” Economics and Politics 7: 207-27.

Kridel, Donald, David E.M. Sappington and Dennis L. Weisman (1996). "The Effects of Incentive Regulation in the Telecommunications Industry: A Survey." Journal of Regulatory Economics 9: 269-306.

Levy, Brian, and Pablo T. Spiller (1994). "The Institutional Foundations of Regulatory Commitment: A Comparative Analysis of Telecommunications Regulation,” Journal of Law, Economics and Organization, 10: 201-46.

and Pablo T. Spiller (1996). Regulations, Institutions and Commitment: Comparative Studies of Telecommunications. Cambridge University Press: New York.

Lewington, Ilka (1997). Utility Regulation 1997: Economic Regulation of Utilities and Network Industries Worldwide. Centre for the Study of Regulated Industries: London.

Londregan, John, and Keith Poole (1996). “Does High Income Promote Democracy?” World Politics 49: 1-30.

Mainwaring, Scott, and Mathew S. Shugart (1997). Presidentialism and Democracy in Latin America. Cambridge University Press: New York. 
Melody, William H. (1997a) “On the Meaning and Importance of 'Independence' in Telecom Reform,” Telecommunications Policy 21: 195-99.

(1997b). Telecom Reform: Principles, Policies and Regulatory Practices. Den private Ingeniprfond, Technical University of Denmark: Lyngby.

Miller, Nicholas (1994). "Regulation: Reconciling Policy Objectives." In Implementing Reforms in the Telecommunications Sector: Lessons from Experience, edited by. B. Wellenius and P. Stern. World Bank: Washington, D.C.

Newbery, David M. (1999). Privatization, Restructuring, and Regulation of Network Utilities, MIT Press: Cambridge, MA.

Noll, Roger G. (1999). Telecommunications Reform in Developing Countries, Working Paper 99-10, AEI-Brookings Joint Center for Regulatory Studies.

Petrazzini, Ben A. (1997). "Regulating Communications Services in Developing Countries" In Telecom Reform: Principles, Policies and Regulatory Practices, edited by W. Melody. Den private Ingeniprfond, Technical University of Denmark, Lyngby.

Pisciotta, Aileen A. (1997). "Global Trends in Privatisation and Liberalisation" In Telecom Reform: Principles, Policies and Regulatory Practices, edited by W. Melody. Den private Ingeniprfond, Technical University of Denmark, Lyngby.

Pyramid Research (1998). Telecom Markets and Strategies: South America. The Economist Intelligence Unit, Ltd.: Cambridge, MA

Sappington, David E. M., and Dennis Weisman.(1996). Designing Incentive Regulation for the Telecommunications Industry. MIT Press: Cambridge, MA.

Schultz, Richard J. (1994.) "Regulation and Telecommunications Reform: Exploring the Alternatives." In Implementing Reforms in the Telecommunications Sector: Lessons from Experience, edited by B. Wellenius and P. Stern. World Bank: Washington, D.C.

Sinha, Nikhil (1995). "Regulatory Reform: An Institutional Perspective." In Telecommunications Politics: Ownership and Control of the Information Highway in Developing Countries, edited by B. Mody, J. Bauer and J. Straubhaar. Lawrence Erlbaum: Mahwah, NJ.

Smith, Peter, and Bjorn Wellenius (1998). "Mitigating the Regulatory Risk in Telecommunications," Public Policy for the Private Sector, Note 189.

Spiller, Pablo T. (1996). "A Positive Political Theory of Regulatory Instruments: Contracts, Administrative Law or Regulatory Specificity?” Southern California Law Review 68: 477-515.

, and Cezley I. Sampson (1996). "Telecommunications Regulation in Jamaica." In Regulations, Institutions and Commitment: Comparative Studies of Telecommunications, edited by B. Levy and P. Spiller. Cambridge University Press: New York.

Stern, Jon (1994.) "Economic Regulation in Central and Eastern Europe," Economics of Transition 2: 391-98. 
(1997). “What Makes an Independent Regulator Independent?” Business Strategy Review 8: $67-74$.

and Stuart Holder (1999). "Regulatory Governance: Criteria for Assessing the Performance of Regulatory Systems: An Application to Infrastructure Industries in the Developing Countries of Asia,” Utilities Policies 8: 33-50

Stiglitz Joseph E. (1998). "Towards a New Paradigm for Development: Strategies, Policies, and Processes." Given as the 1998 Prebisch Lecture at UNCTAD, Geneva.

Tenenbaum, Bernard (1996.) "Regulation: What the Prime Minister Needs to Know," Electricity Journal 13: 28-36.

Tirole, Jean (1994). "The Internal Organization of Government," Oxford Economic Papers 46: 129.

Townsend, David (1994). "The Vital Role of Regulation in the Telecommunications Sector." In Implementing Reforms in the Telecommunications Sector: Lessons from Experience, edited by B. Wellenius and P. Stern. World Bank: Washington, D.C.

Tyler, Michael, and Susan Bednarczyk (1993). "Regulatory Institutions and Processes in Telecommunications: An Alternative Study of Alternatives," Telecommunications Policy 17: 650-76.

Williamson, John (1990). "What Washington means by Policy Reform", In Latin American Adjustment: How Much Has Happened? edited by J. Williamson. Institute for International Economics, Washington, D.C.

Williamson, Oliver (1998). "Economic Institutions and Development: A View from the Bottom," In A Not-so-Dismal Science, edited by M. Olson and S. Kaohnen. Oxford University Press: New York. 